\title{
Epidermal Growth Factor Receptor Mutation in a Patient with Squamous Cell Carcinoma of the Lung: Who Should Be Tested?
}

\author{
Michael Schwitter ${ }^{\mathrm{a}} \quad$ Regulo Rodriguez $^{\mathrm{b}} \quad$ Tino Schneider $^{\mathrm{c}}$ \\ Thomas Kluckert $^{d} \quad$ Martin Brutsche ${ }^{c} \quad$ Martin Früh $^{a}$ \\ ${ }^{a}$ Department of Medical Oncology and Hematology, ${ }^{b}$ Institute of Pathology, \\ ${ }^{\mathrm{C}}$ Department of Pneumology, and ${ }^{\mathrm{d}}$ Institute of Radiology, Kantonsspital St. Gallen, \\ St. Gallen, Switzerland
}

\section{Key Words}

Non-small cell lung cancer · Squamous cell carcinoma - Epidermal growth factor receptor mutation $\cdot$ Immunohistochemistry $\cdot$ Histology

\begin{abstract}
We report the case of a 64-year-old ex-smoker with metastatic poorly differentiated squamous cell carcinoma (SCC) of the lung and an epidermal growth factor receptor (EGFR) mutation in exon 21 (p.L858R) who achieved prolonged clinical benefit from treatment with an EGFR tyrosine kinase inhibitor (TKI). The initial diagnosis of SCC of the lung obtained by bronchoscopic biopsy was based on immunohistochemical staining only with positivity for cytokeratin (CK) 5/6 and p63 because morphological diagnosis was not possible. Patients with non-small cell lung cancer (NSCLC), not otherwise specified (NOS) favouring SCC are usually not tested for the presence of EGFR mutations, and therefore may not receive EGFR TKI therapy. A bronchoscopic rebiopsy showed small nests of undifferentiated tumour cells with weak immunoreactivity of some tumour cells for CK5/6, p63 and no positivity of some tumour cells for thyroid transcription factor- 1 . These findings suggested a mixed squamous/glandular immunophenotype that has been missed at the initial biopsy. Our clinical case illustrates the problem of tumour heterogeneity encountered in small bronchoscopic biopsies and the difficulties of evaluating the histological subtype in poorly differentiated carcinomas. Initial bronchoscopy should be performed by an experienced pulmonologist who attempts to obtain sufficient material from different areas of the tumour. In the era of targeted therapy, a remote smoking history in a patient with NOS favouring SCC should also
\end{abstract}

Martin Früh, MD

Department of Medical Oncology and Hematology

Kantonsspital St. Gallen

CH-9007 St. Gallen (Switzerland)

E-Mail Martin.Frueh@kssg.ch 
lead to EGFR mutation testing to allow highly effective therapy to be offered to mutationpositive patients.

\section{Case Description}

An otherwise healthy 64-year-old Caucasian man presented with worsening right inguinal pain since 3 months. He had a 30 pack-years smoking history until 25 years ago. A computed tomography scan showed a $7 \times 7.5-\mathrm{cm}$ mass infiltrating the right psoas muscle, a right-sided hilar lung lesion, enlarged ipsilateral mediastinal lymph nodes and a $4.5 \times 3-\mathrm{cm}$ adrenal mass. A bronchoscopic biopsy confirmed a poorly differentiated carcinoma, positive for p63, CK5/6 and negative for TTF-1 (thyroid transcription factor-1) on immunohistochemical staining (fig. 1a-d). The pathology report stated a poorly differentiated squamous cell carcinoma (SCC) of the lung, and systemic therapy was initiated. Unfortunately, the patient progressed after two cycles of first-line chemotherapy with carboplatin and paclitaxel and subsequently received palliative radiotherapy with 50 Gy for the psoas metastasis and the primary tumour. In addition, an epidermal growth factor receptor (EGFR) mutation analysis from the initial tumour material revealed an activating point mutation in exon 21 (p.L858R). The EGFR tyrosine kinase inhibitor (TKI) erlotinib was started resulting in a partial remission after 8 weeks of therapy, and the patient became asymptomatic and unrestricted in his physical activity (fig. 2). Twenty-two months later, he developed multifocal progression with lung and liver metastases. A bronchoscopic rebiopsy showed small nests of undifferentiated tumour cells with weak immunoreactivity of some tumour cells for p63, CK5/6 and also positivity of some tumour cells for TTF-1, suggesting a mixed squamous/glandular immunophenotype (fig. 3a-d). Third-line chemotherapy remained unsuccessful, and the patient died 33 months after initial diagnosis.

\section{Discussion}

Median survival rates in chemotherapy-refractory, unselected patients are less than 6 months with either erlotinib or chemotherapy [1]. Second-line EGFR TKIs are offered to fewer than $25 \%$ of these patients [1]. If EGFR mutation testing had not been performed, our patient would have likely missed the opportunity of having a symptom-free period of almost 2 years with EGFR TKI therapy. Several factors are known to be associated with the presence of an activating EGFR mutation: female gender, non-smoking history, Asian ethnicity and adenocarcinoma. The incidence of EGFR mutations in SCC is rare, particularly in Caucasian patients $(<5 \%)$ [2]. A study on 95 resected pure SCC patients suggested that EGFR mutations are usually absent [3]. According to the recent ESMO guidelines, molecular testing is recommended in never or former light smokers ( $<15$ pack-years) with SCC of the lung [4]. Since none of these clinico-pathological criteria applied to the patient, the EGFR mutation has not been determined at initial diagnosis.

The pathological diagnosis of lung tumours is based on the 2004 WHO criteria [5]. Of note, this classification was established on resected tumour material, which is available in only $30 \%$ of non-small cell lung cancer (NSCLC) patients. Our case illustrates several pitfalls in determining the histological subtype. The morphological diagnosis of SCC was not possible due to the lack of keratinisation and intercellular bridges. Therefore, immunohistologic staining to assist in the identification of the histological subtype is recommended [6]. The most important antibodies include TTF-1, CK5/6, and p63. Although a high correlation 
Schwitter et al.: Epidermal Growth Factor Receptor Mutation in a Patient with Squamous Cell Carcinoma of the Lung: Who Should Be Tested?

with SCC and positive immunoreactivity for CK5/6 and p63 have been reported, the correct wording of the initial pathology report should have been NSCLC, not otherwise specified (NOS) favouring SCC according to the immunohistologic markers [6, 7]. This classification has recently been proposed for small biopsies/cytology samples to clarify whether diagnosis was based on morphology or special stains [6]. However, only patients with adenocarcinoma (i.e. morphological diagnosis), NSCLC NOS favouring adenocarcinoma (i.e. special stains) and patients with NSCLC NOS are generally considered for EGFR mutation testing in clinical practice. In patients with a clear morphological diagnosis of SCC or NSCLC NOS favouring SCC, routine testing is not recommended [6]. It is very important to keep in mind that all current clinical trials justifying the importance of the distinction between histologic types are based on light microscopy alone, and our knowledge on the incidence of activating EGFR mutations in patients with true NSCLC NOS and NSCLC NOS favouring adenocarcinoma or SCC according to immunohistochemical marker profile is limited [8-11]. Our case raises the question whether EGFR mutation testing should be advocated in all patients with a bioptic diagnosis of NSCLC who morphologically lack glandular or squamous differentiation (i.e. NOS), independent of the results of specific stains, particularly in patients with clinical characteristics commonly associated with an EGFR mutation such as a remote smoking history in our patient.

Rebiopsy after progression on EGFR TKI therapy immunohistochemically suggested the presence of a mixed adenosquamous subtype, a condition described in approximately $5 \%$ of NSCLC on resected tumour tissue [6]. Although bronchoscopic biopsies have the advantage of being minimally invasive compared to surgical biopsies, they carry the risk of containing a variable amount of tumour tissue that may not be representative for the tumour burden as a whole, and a mixed adenosquamous subtype may be overlooked (sampling error).

Our case illustrates the importance of a multidisciplinary approach and close collaboration among pulmonologists, pathologists and oncologists in treating patients with stage IV NSCLC. Due to tumour heterogeneity, every effort should be made by the experienced pulmonologist to obtain sufficient material from different areas of the tumour. In our opinion, a remote smoking history in a patient with NSCLC NOS favouring SCC should also lead to EGFR mutation testing to allow highly effective therapy to be offered to mutationpositive patients. Genetic analyses such as high-throughput gene profiling and miRNA studies hold promise in supporting classification of lung cancer subtypes and have the potential to assist the classical morphologic and immunohistochemical diagnosis in the near future.

\section{Disclosure Statement}

The authors report no conflicts of interest.

\section{References}

1 Ciuleanu T, Stelmakh L, Cicenas S, Miliauskas S, Grigorescu AC, Hillenbach C, Johannsdottir HK, Klughammer B, Gonzalez EE: Efficacy and safety of erlotinib versus chemotherapy in second-line treatment of patients with advanced, non-small-cell lung cancer with poor prognosis (TITAN): a randomised multicentre, openlabel, phase 3 study. Lancet Oncol 2012;13:300-308.

2 Perez-Moreno P, Brambilla E, Thomas R, Soria JC: Squamous cell carcinoma of the lung: molecular subtypes and therapeutic opportunities. Clin Cancer Res 2012;18:2443-2451. 


\begin{tabular}{l|l}
\hline DOI: $10.1159 / 000351607$ & $\begin{array}{l}\text { (c) } 2013 \text { S. Karger AG, Basel } \\
\text { www.karger.com/cro }\end{array}$ \\
\hline
\end{tabular}

Schwitter et al.: Epidermal Growth Factor Receptor Mutation in a Patient with Squamous Cell Carcinoma of the Lung: Who Should Be Tested?

-3 Rekhtman N, Paik PK, Arcila ME, Tafe LJ, Oxnard GR, Moreira AL, Travis WD, Zakowski MF, Kris MG, Ladanyi M: Clarifying the spectrum of driver oncogene mutations in biomarker-verified squamous carcinoma of lung: lack of EGFR/KRAS and presence of PIK3CA/AKT1 mutations. Clin Cancer Res 2012;18:1167-1176.

-4 Peters S, Adjei AA, Gridelli C, Reck M, Kerr K, Felip E; ESMO Guidelines Working Group: Metastatic nonsmall-cell lung cancer (NSCLC): ESMO Clinical Practice Guidelines for diagnosis, treatment and follow-up. Ann Oncol 2012;23(suppl 7):vii56-vii64.

5 Travis WD, Brambilla E, Muller-Hermelink HK, Harris CC: Pathology and Genetics. Tumours of the Lung, Pleura, Thymus and Heart. Lyon, IARC Press, 2004.

-6 Travis WD, Brambilla E, Noguchi M, Nicholson AG, Geisinger KR, Yatabe Y, Beer DG, Powell CA, Riely GJ, Van Schil PE, Garg K, Austin JH, Asamura H, Rusch VW, Hirsch FR, Scagliotti G, Mitsudomi T, Huber RM, Ishikawa Y, Jett J, Sanchez-Cespedes M, Sculier JP, Takahashi T, Tsuboi M, Vansteenkiste J, Wistuba I, Yang PC, Aberle D, Brambilla C, Flieder D, Franklin W, Gazdar A, Gould M, Hasleton P, Henderson D, Johnson B, Johnson D, Kerr K, Kuriyama K, Lee JS, Miller VA, Petersen I, Roggli V, Rosell R, Saijo N, Thunnissen E, Tsao M, Yankelewitz D: International association for the study of lung cancer/american thoracic society/european respiratory society international multidisciplinary classification of lung adenocarcinoma. J Thorac Oncol 2011;6:244-285.

7 Mukhopadhyay S, Katzenstein AL: Subclassification of non-small cell lung carcinomas lacking morphologic differentiation on biopsy specimens: utility of an immunohistochemical panel containing TTF-1, napsin A, p63, and CK5/6. Am J Surg Pathol 2011;35:15-25.

8 Mok TS, Wu YL, Thongprasert S, Yang CH, Chu DT, Saijo N, Sunpaweravong P, Han B, Margono B, Ichinose Y, Nishiwaki Y, Ohe Y, Yang JJ, Chewaskulyong B, Jiang H, Duffield EL, Watkins CL, Armour AA, Fukuoka M: Gefitinib or carboplatinpaclitaxel in pulmonary adenocarcinoma. N Engl J Med 2009;361:947-957.

-9 Mitsudomi T, Morita S, Yatabe Y, Negoro S, Okamoto I, Tsurutani J, Seto T, Satouchi M, Tada H, Hirashima T, Asami K, Katakami N, Takada M, Yoshioka H, Shibata K, Kudoh S, Shimizu E, Saito H, Toyooka S, Nakagawa K, Fukuoka M; West Japan Oncology Group: Gefitinib versus cisplatin plus docetaxel in patients with nonsmall-cell lung cancer harbouring mutations of the epidermal growth factor receptor (WJTOG3405): an open label, randomised phase 3 trial. Lancet Oncol 2010;11:121-128.

10 Maemondo M, Inoue A, Kobayashi K, Sugawara S, Oizumi S, Isobe H, Gemma A, Harada M, Yoshizawa H, Kinoshita I, Fujita Y, Okinaga S, Hirano H, Yoshimori K, Harada T, Ogura T, Ando M, Miyazawa H, Tanaka T, Saijo Y, Hagiwara K, Morita S, Nukiwa T; North-East Japan Study Group: gefitinib or chemotherapy for nonsmall-cell lung cancer with mutated EGFR. N Engl J Med 2010;362:2380-2388.

11 Zhou C, Wu YL, Chen G, Feng J, Liu XQ, Wang C, Zhang S, Wang J, Zhou S, Ren S, Lu S, Zhang L, Hu C, Hu C, Luo Y, Chen L, Ye M, Huang J, Zhi X, Zhang Y, Xiu Q, Ma J, Zhang L, You C: Erlotinib versus chemotherapy as firstline treatment for patients with advanced EGFR mutation-positive non-small-cell lung cancer (OPTIMAL, CTONG-0802): a multicentre, open-label, randomised, phase 3 study. Lancet Oncol 2011;12:735-742. 


\section{Case Reports in Oncology}

\begin{tabular}{l|l}
\hline Case Rep Oncol 2013;6:263-268 \\
\hline DOI: $10.1159 / 000351607$ & $\begin{array}{l}\text { C 2013 S. Karger AG, Basel } \\
\text { www.karger.com/cro }\end{array}$ \\
\hline
\end{tabular}

Schwitter et al.: Epidermal Growth Factor Receptor Mutation in a Patient with Squamous Cell Carcinoma of the Lung: Who Should Be Tested?

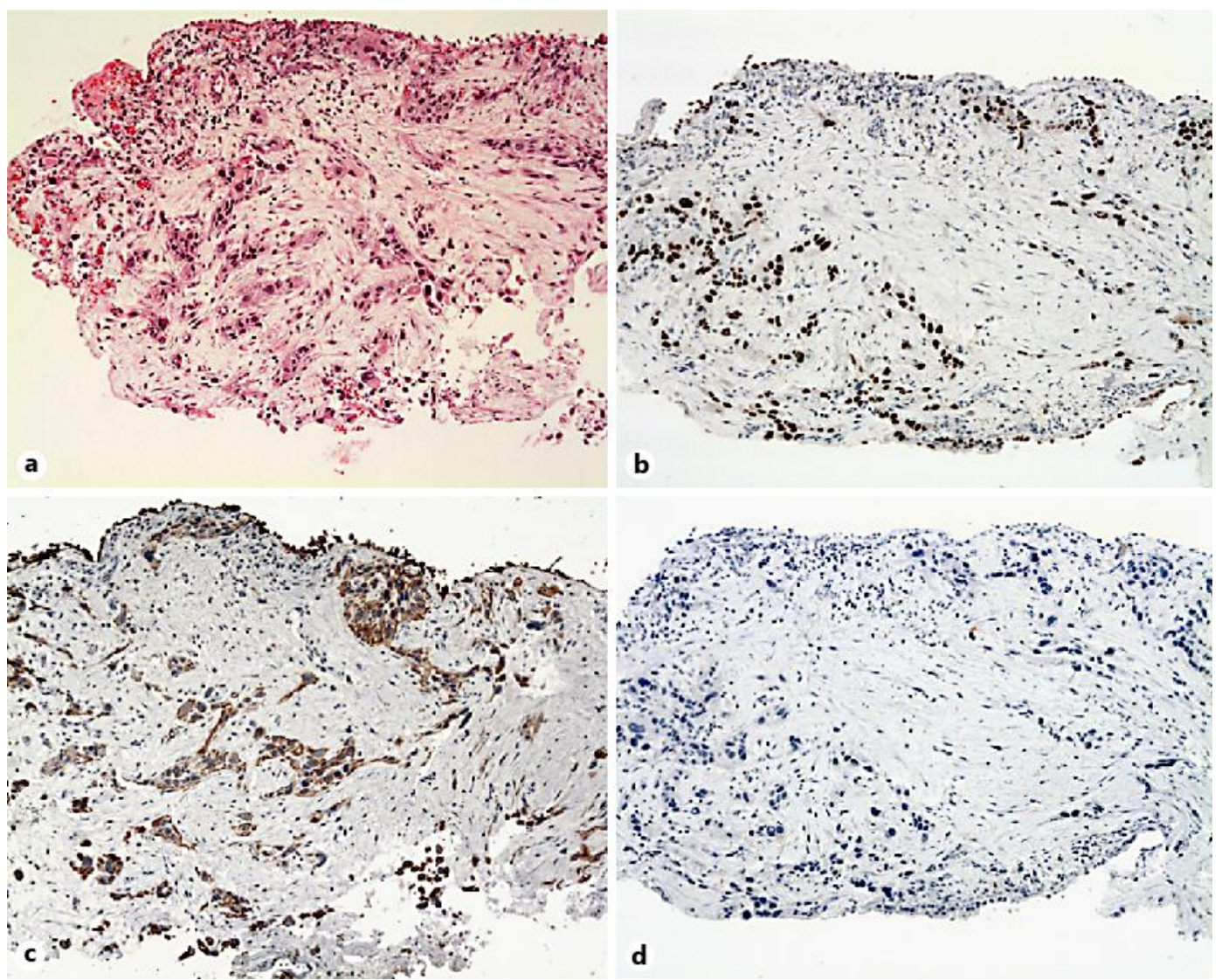

Fig. 1. a-d Bronchus biopsies showing circumscribed infiltrates of a poorly differentiated NSCLC with a squamous immunophenotype. The tumour cells are positive for p63, CK5/6 and negative for TTF-1. No dyskeratosis or clear intercellular bridges are seen.

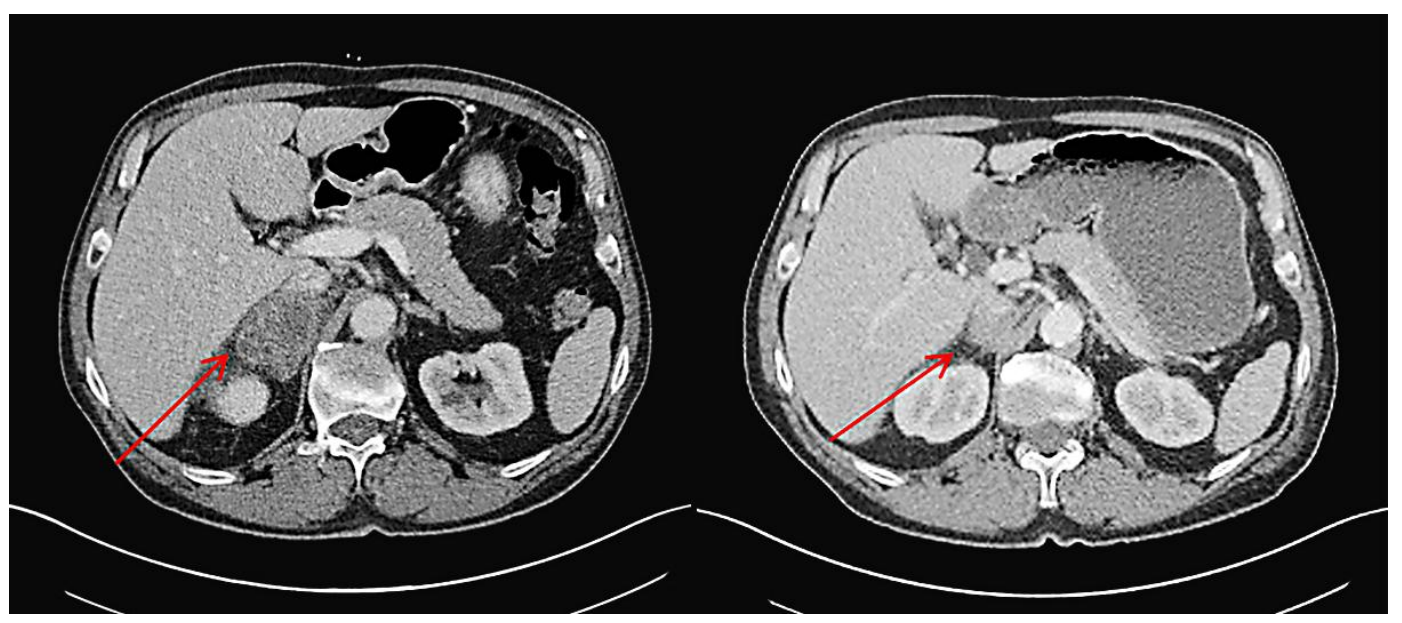

Fig. 2. Computed tomography scans before and after 2 months of treatment with erlotinib. 


\section{Case Reports in Oncology}

Case Rep Oncol 2013;6:263-268

DOI: $10.1159 / 000351607$

Schwitter et al. Epidermal Growth Factor Receptor Mutation in a Patient with

Squamous Cell Carcinoma of the Lung: Who Should Be Tested?

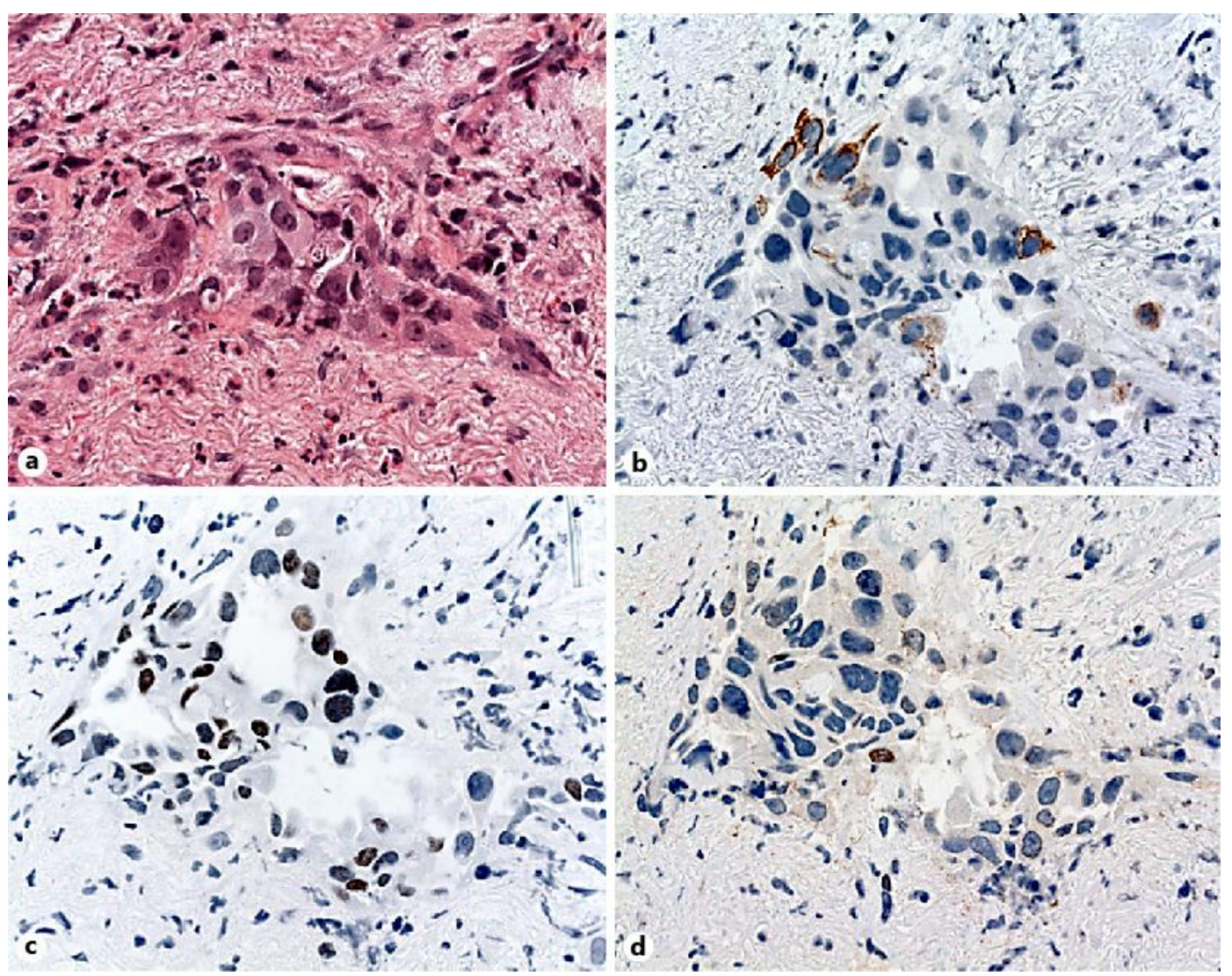

Fig. 3. a-d Rebiopsies showing sparse, small nests of tumour cells of morphological NSCLC-NOS with focal loss of cell cohesiveness. Only some tumour cells show a weak immunoreactivity for p63, CK5/6 and a new positivity for TTF-1, corresponding to a mixed squamous and glandular immunophenotype. 